\title{
Genotoxicity: Mechanisms, Testing Guidelines and Methods
}

\author{
Mohamed SAKS, Sabita Upreti, Rajendra SV* and Raman Dang \\ Krupanidhi College of Pharmacy, India
}

Submission: March 08, 2017; Published: April 27, 2017

*Corresponding author: Rajendra SV, Department of Pharmacology, Krupanidhi College of Pharmacy, India, Tel: 7895225540; Email: drrajendra1972@gmail.com

\begin{abstract}
Genotoxicity is one of the major causes for cancer. Genotoxins are agents that can cause the damage of DNA or chromosomal structure thereby causing mutations. It can be chemical or radiation. This damage in the somatic cells will lead to various diseases ranging to cancer whereas the damage to the germ cell will lead to heritable diseases. Better identification and understanding of genotoxins would enable us to prevent the potential damage that can be caused by these genotoxic agents. In this article we discuss about the basic of genotoxicity and the importance of genotoxic studies.
\end{abstract}

Keywords: Genotoxins, Mutagens, DNA Damage, Chromosomal mutation, Testing guidelines.

\section{Introduction}

Genotoxicity is a word used in genetics that describes the possession of substance that has destructive effect on the genetic material of the cell (DNA, RNA) thus affecting the integrity of the cell. Genotoxins are mutagens that can cause genotoxicity leading to the damage of DNA or chromosomal material thus causing mutation. Genotoxins can include chemical substance as well as radiation. Genetic toxicology is the branch of science that deals with the study of agents or substances that can damage the cell's DNA and chromosomes. It is noted that often genotoxicity is confused with mutagenicity. All mutagens are genotoxic however all genotoxic substances are not mutagenic [1].

Genotoxins can be of the following category depending on its effects [2]:

o Carcinogens or cancer causing agents

o Mutagens or mutation causing agents

o Teratogens or birth defect causing agents

The damage of genetic material of somatic cells may lead to malignancy (cancer) in eukaryotic organisms. Whereas the genetic damage of the germ cells may lead to heritable mutations causing birth defects (Figure 1). Mutations can be of any form; which may include duplication, insertion or deletion of genetic information. These mutations can cause varying range of problems in the host, from a wide variety of diseases to cancer
$[3,4]$ One of the best ways to control the damage due to mutagens and carcinogens is to identify the substance or chemical, i.e. antimutagens /anticlastogens (which suppress or inhibit the mutagenesis process by directly acting on the cell mechanism) and demutagens (which destroy or inactivate the mutagens partially or fully thereby affecting less population of cell) from the medicinal plants so that it can be used as antimutagenic and anticarcinogenic food or drug additives [5-7].

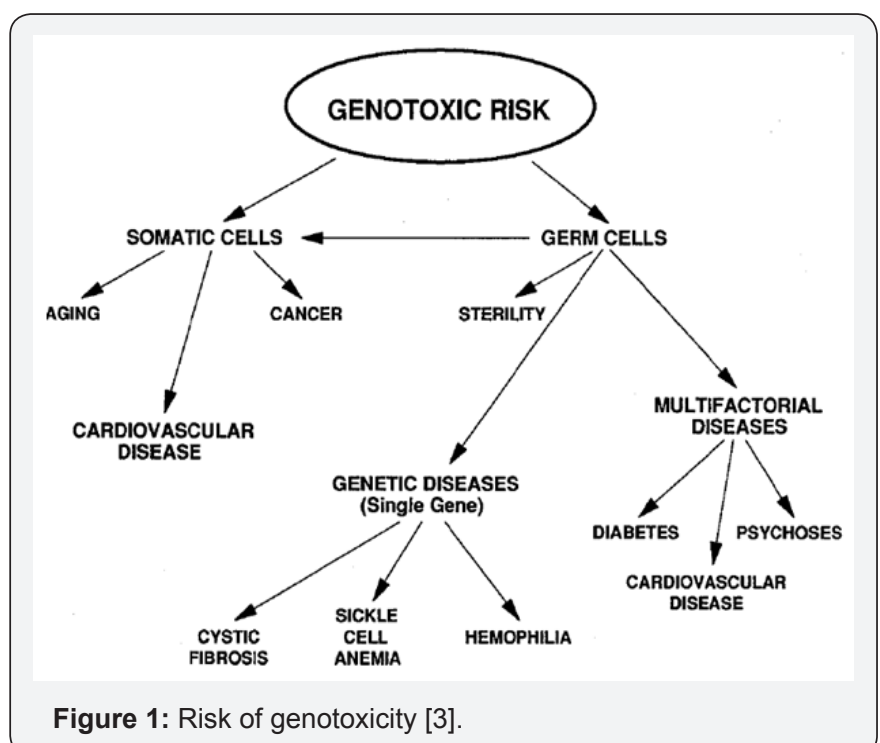




\section{Importance of genotoxicity studies}

Genotoxicity studies can be defined as various in-vitro and in-vivo tests designed to identify any substance or compounds which may induce damage to genetic material either directly or indirectly by various mechanisms. These tests should enable the identification of hazard with respect to DNA damage and fixation [8]. Genetic change play only a part in the complex process of heritable effects and malignancy which include the fixation of the damage to the DNA by gene mutation or large scale chromosomal damage or recombination or numerical chromosomal changes. These tests play an important role in predicting if the compound have the potential to cause genotoxicity and carcinogenicity by testing them positive [9]. As a part of safety evaluation process, regulatory authorities all over the globe require information on the genotoxic potential of the new drugs. Genotoxicity is usually evaluated along with other toxicological end points during the safety assessment [10] (Figure 2).

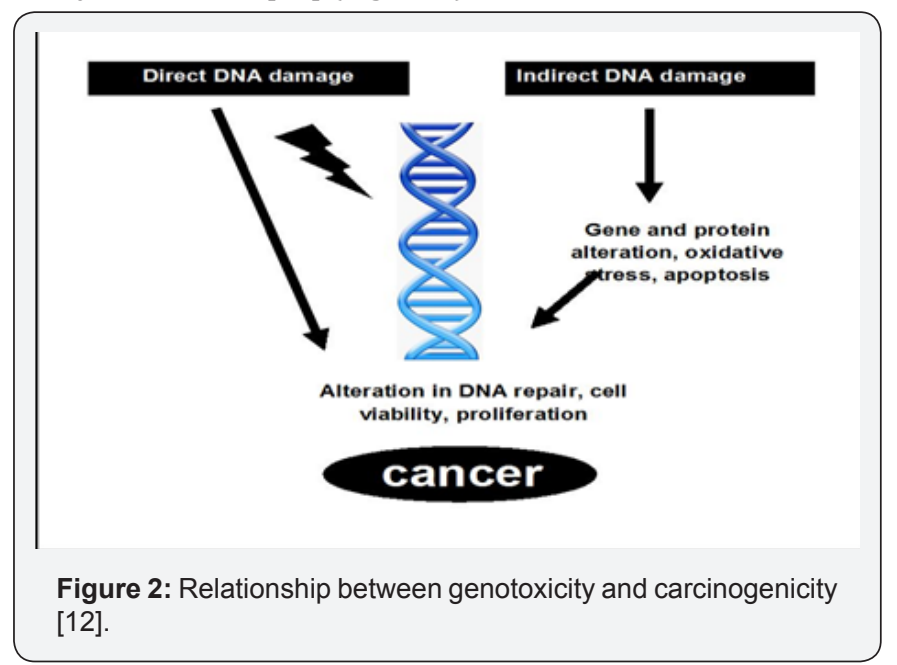

During the early testing stages; the same testing assays are carried out for predicting both the potential heritable germ cell damage as well as the carcinogenicity because these endpoints have common precursors. The relationship between exposure to particular chemical and carcinogenesis has been established whereas such relationship has been difficult to establish for heritable diseases, genotoxic studies have been mainly associated and used for the prediction of carcinogenicity of a compound $[11,12]$

\section{Classifiaction of carcinogens}

EU classification of carcinogens [13]

o Carcinogen category 1-shown to cause cancer in humans

o Carcinogen category 2-causes cancer in animal tests, and most probably also in humans

o Carcinogen category 3-possibly carcinogenic, but evidence supporting carcinogenicity is inadequate for the classification to category 2 .
Iarc (International Agency For Research On Cancer) classification of carcinogens [4]

o IARC class 1-The substance is carcinogenic to humans.

o IARC class 2A-The substance is probably carcinogenic to humans.

o IARC class 2B-The substance is possibly carcinogenic to humans.

o IARC class 3-The substance is not classifiable to as to its carcinogenicity to humans.

o IARC class 4-The substance is probably not carcinogenic to humans.

\section{Agents that can cause direct or indirect damage to the DNA}

Reactive oxygen species are known to be genotoxic in nature, thus any chemical or substance that may increase the reactive oxygen species (ROS) production might evidently add to the endogenously produced ROS and may lead to non-linear relationships of dose-effect. The following agents are capable of damaging the DNA directly or indirectly; [14]

o Electrophilic species that form covalent adducts to the DNA

o Reactive oxygen species

o Ultra violet and ionizing radiations.

o Nucleoside analogues

o Topoisomerase inhibitors

o Protein synthesis inhibitors

o Some herbal plants like Aconite, Alfa-alfa, Calamus, Aloe vera, Isabghol etc.

Anti-mutagen is any agent that decreases the effect of spontaneous and induced mutations. There are mainly two mechanisms of anti-mutagenesis:

a. Desmutagenesis in which the factors on the mutagens are somehow inactivated,

b. Bio-antimutagenesis, in which the factors act on the process of mutagenesis or by repairing the damaged DNA that result in the decreased frequency of DNA mutation [15]. Our cells have several DNA repair system by which they try to control the DNA mutations naturally.

The five major pathways through which the cell repair the damaged DNA are: [16-19]

o $\quad$ Direct repair

o $\quad$ Base excision repair( BER)

o Nucleotide excision repair (NER) 


\section{Global Journal of Pharmacy \& Pharmaceutical Sciences}

o $\quad$ Mismatch repair

Single/ double strand break repair

\section{Mechanism of genotoxicity}

The damage to the genetic material is caused by the interactions of the genotoxic substance with the DNA structure and sequence. These genotoxic substance interact at a specific location or base sequence of the DNA structure causing lesions, breakage, fusion, deletion, mis-segregation or non- disjunction leading to damage and mutation [20]. For example, in its high-valent oxidation state the transition metal chromium interacts with the DNA so that DNA lesions occur leading to carcinogenesis. Researchers have found that the mechanism of damage and base oxidation products for the interaction between DNA and high-valent chromium are relevant to in-vivo formation of DNA damage leading to cancer in chromate- exposed human population, thus making high valent chromium a carcinogen (Figure 3).

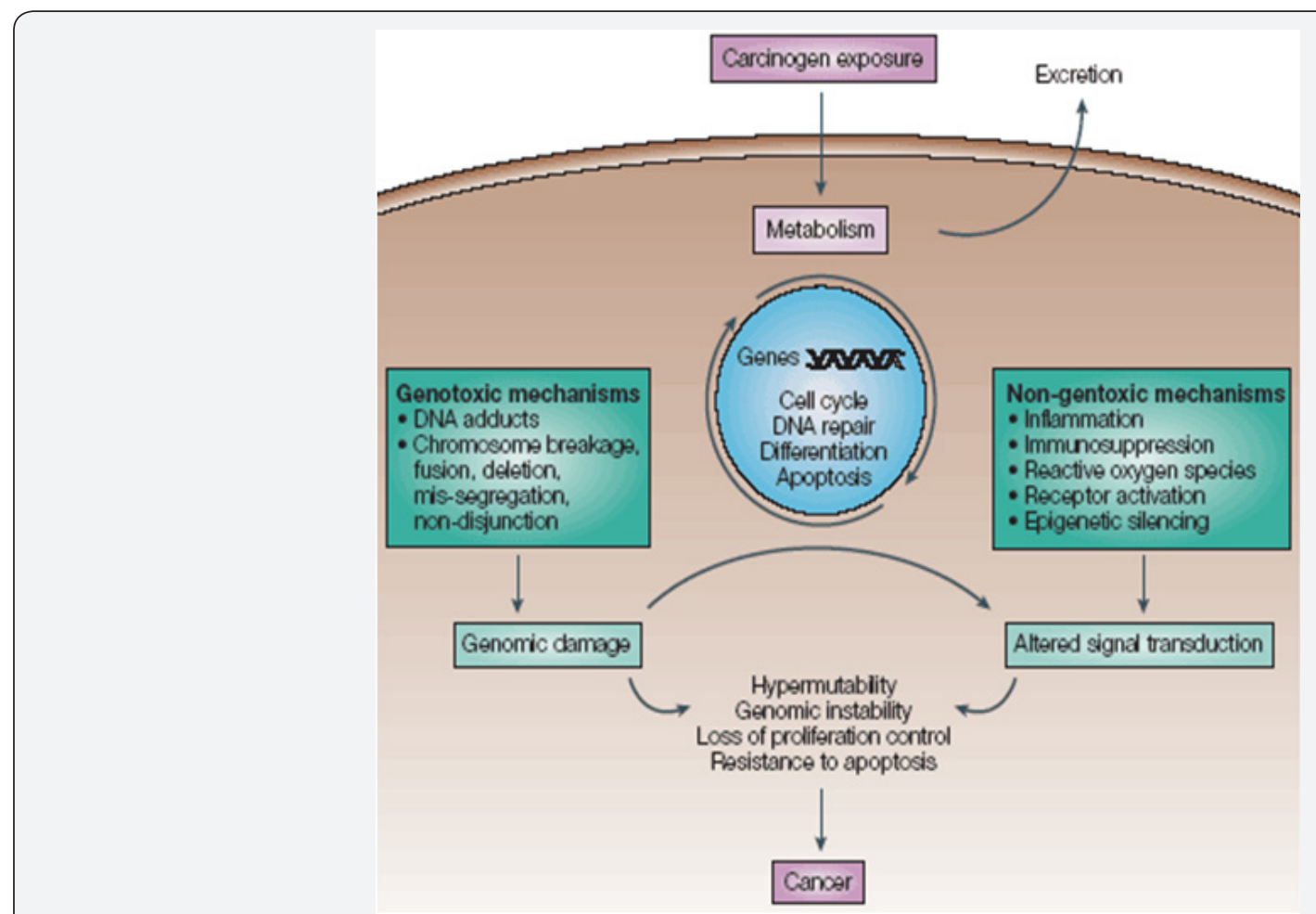

Figure 3: Mechanism of carcinogenesis [22].

Reactive oxygen species causes one of the most abundant oxidative lesions in DNA and is 8- hydroxydeoxyguanosine (8$\mathrm{OHdG}$ ), which is a potent mutagenic lesion. Oxidants as well as free radical when present in the cellular system can adversely affect and alter the structure of lipids, proteins as well as DNA. Reactive aldehydes like 4-hydroxynonenal (4-HNE) are generated by the decomposition of lipid peroxyl radicals or primary free radical intermediate of lipid peroxidation. 4-Hydroxynonenal is involved in many of the oxidative stress related diseases such as atherosclerosis, fibrosis, neurodegenerative diseases it. Many studies have indicated that 4-Hydroxynonenal can stimulate the cell proliferation, differentiation as well as cytoprotective response through its effects on various signalling pathway [21].

\section{Standard test battery for genotoxicity}

The standard test battery for genotoxicity recommends the following for genotoxicity

Evaluation [22-24] (Table 1).
Table 1: The standard test battery for genotoxicity recommends the following for genotoxicity Evaluation.

\begin{tabular}{|c|c|}
\hline TG 471 & Bacterial Reverse Mutation Test (Ames Test) \\
\hline TG 472 & Genetic Toxicology: Escherichia coli, reverse assay \\
\hline TG 473 & In-Vitro Mammalian Chromosome Aberration Test \\
\hline TG 474 & Mammalian Erythrocyte Micronucleus Test \\
\hline TG 475 & Mammalian Bone Marrow Chromosome Aberration Test \\
\hline TG 476 & In-Vitro Mammalian Cell Gene Mutation Test \\
\hline TG 477 & $\begin{array}{c}\text { Genetic Toxicology: Sex-linked Recessive Lethal Test in } \\
\text { Drosophila melanogaster }\end{array}$ \\
\hline TG 478 & Genetic Toxicology: Rodent Dominant Lethal Test \\
\hline TG 479 & $\begin{array}{c}\text { Genetic Toxicology: In-Vitro Sister Chromatid Exchange } \\
\text { Assay in Mammalian Cells }\end{array}$ \\
\hline TG 480 & $\begin{array}{c}\text { Genetic Toxicology: Saccharomyces cerevisiae, Gene } \\
\text { Mutation Assay }\end{array}$ \\
\hline
\end{tabular}




\section{Global Journal of Pharmacy \& Pharmaceutical Sciences}

\begin{tabular}{|c|c|}
\hline TG 481 & $\begin{array}{c}\text { Genetic Toxicology: Saccharomyces cerevisiae, Mitotic } \\
\text { Recombination Assay }\end{array}$ \\
\hline TG 482 & $\begin{array}{c}\text { Genetic Toxicology: DNA Damage and Repair, Unscheduled } \\
\text { DNA Synthesis in Mammalian Cells In-Vitro }\end{array}$ \\
\hline TG 483 & Mammalian Spermatogonial Chromosome Aberration Test \\
\hline TG 484 & Genetic Toxicology: Mouse Spot Test \\
\hline TG 485 & Genetic Toxicology: Mouse Heritable Translocation Assay \\
\hline
\end{tabular}

\begin{tabular}{|c|c|}
\hline TG 486 & $\begin{array}{c}\text { Unscheduled DNA Synthesis (UDS) Test with Mouse Liver } \\
\text { Cells In-Vitro }\end{array}$ \\
\hline TG 487 & In-Vitro Mammalian Cell Micronucleus Test \\
\hline
\end{tabular}

o Testing for gene mutation in bacteria

o In-vitro: cytogenetic evaluation of chromosomal damage with mammalian cells or mouse lymphoma assay.

o In-vivo: test for chromosomal damage using rodent hematopoietic cells (Figure 4).

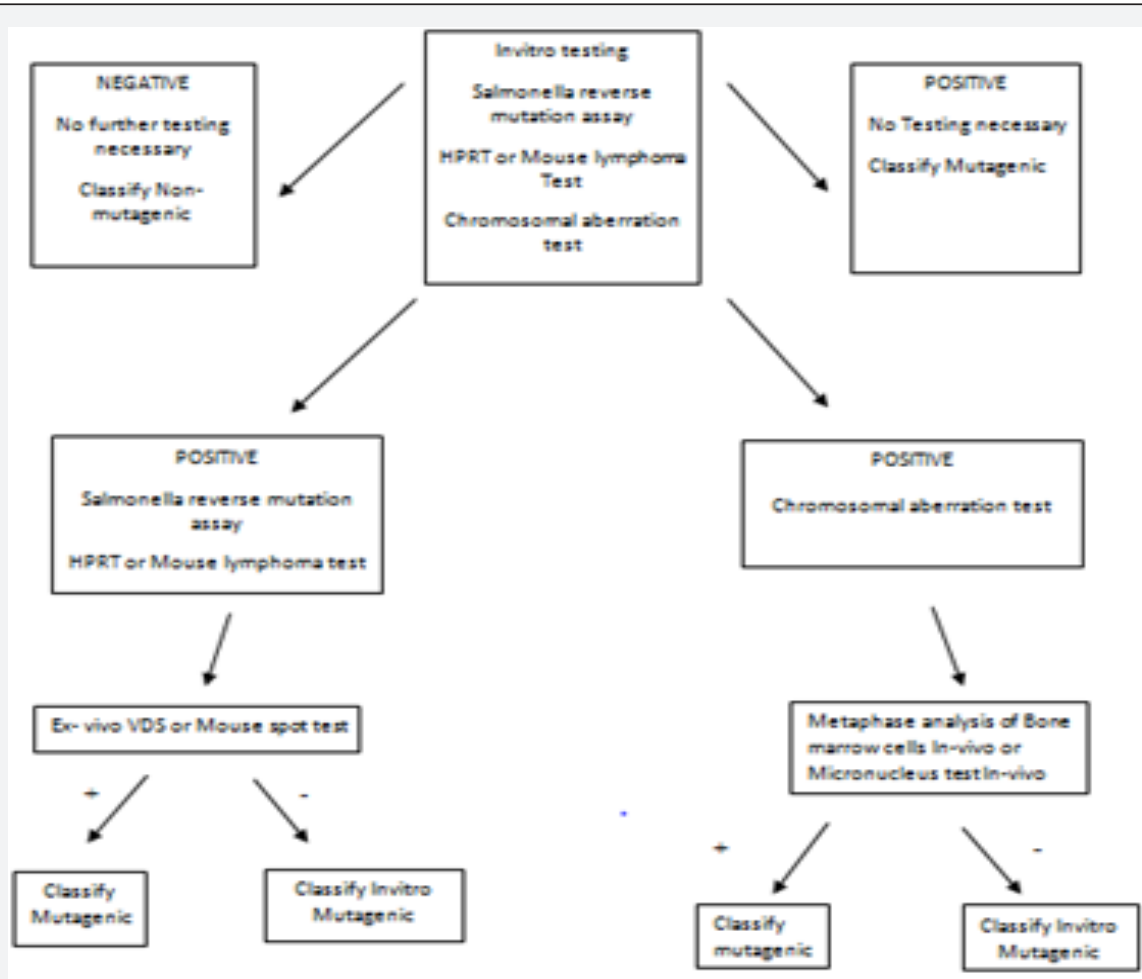

Figure 4: Flow chart on Genotoxicity Testing [26].

\section{Purpose of genotoxicity assays}

Assays even though inexpensive, have high statistical power and can be reproduced and have the ability to detect a wide variety of genotoxic end-points. It also allows the detection of a drug's potential to cause genotoxicity even in the early stage of drug development. They are designed in such a way that it can be more sensitive to damage so as to enhance the identification of hazard $[25,26]$.

\section{In-Vitro testing methods}

There are many in-vitro genotoxicity testing methods available. Some of the commonly used tests which are also a part of the standard battery are [27]:

- Bacterial reverse mutation test which is otherwise called as Ames test whose endpoint is the gene mutations in the bacterial cell [28-29].
- Mammalian chromosome aberration test with the end point of chromosome aberration [30-31].

- Mammalian cell gene mutation test or the mouse lymphoma test whose end point is the gene mutations [32,33].

Bacterial reverse mutation test: The Bacterial reverse mutation test was developed by Ames. B thus the name Ames test. The amino acid requiring strains of Salmonella typhimurium and Escherichia coli are used in the bacterial reverse mutation test to detect the mutation points which may involve substitution, deletion or addition of one or few of base pairs of DNA [34]. The main principle of the test is that after identifying the mutation it reverts it back and restore the functional capability of the mutant cell to synthesize Histidine. In this test the reverent bacteria cells are identified by the ability of the parent test strain to grow in the absence of amino acids. The bacterial reverse mutation test being rapid, inexpensive and easy to perform is commonly 
used as an initial screening test for genotoxicity or mutagenicity $[35,36]$.

Mammalian chromosome aberration test: The main purpose of the mammalian chromosome aberration test is to identify the agents which can cause structural mutations in chromosomes or chromatids, chromatid mutation being the common [37,38]. Other type of chromosomal changes like polyploidy and duplication can also be found using this test. A positive test result shows a potential mutagenic or carcinogenic of the agent but there is not a perfect correlation [39].

Mammalian cell gene mutation test: This test is used to find the gene mutations caused by the chemical substances. The commonly used cell lines include L5178Y mouse lymphoma cells, the CHO, CHO-AS52 and V79 lines of Chinese hamster cells, and TK6 human lymphoblastic cells [40-41]. It detects the end points like thymidine kinase (TK) and hypoxanthine-guanine phosphoribosyltransferase (HPRT), and a transgene of xanthineguanine phosphoribosyltransferase (XPRT) mutation [42,43].

\section{In-vivo genotoxicity testing methods}

The in-vivo genotoxicity test or assays are done supplemental to in-vitro assay if an in-vitro positive result is obtained. Some of the in-vivo tests done are as follows [44].

In-vivo comet assay: It is one of the commonly used in-vivo test used for hazard assessment of agents which have potential for genotoxicity or mutagenicity [45]. It helps in detecting the DNA damage and detects a broad variety of primary DNA lesions which cannot be identified by any other tests. This test can be applied to a wide variety of tissues or any special cell types. Being sensitivity to even low level of DNA damage it requires only small amount of cells per sample and it can be completed in a short period of time [46].

In-vivo micronuclei test/In-vivo chromosome aberration test: It is a test done to identify the damage done chromosome or spindles. On exposure to the mutagen the cell may undergo damage and on division it will form smaller micronucleus additional to the main nucleus [47].

\section{Conclusion}

Genotoxins are agents that can interact with the DNA thus causing mutations and damaging its structure and may lead to cancer. They act by changing the chromosomal structure by addition, deletion, duplication, forming rings etc. The mutations may lead to a wide variety of diseases to cancer. It is very important to do genotoxicity studies so as to avoid the potential damage that can be caused by it. These genotoxicity tests are done to identify if a drug or other substance have the potential to cause mutation and genotoxicity. By doing so they help us identifying the hazards in the early stage of drug development itself. Identification of the genotoxic agents helps us understand the mechanism of the mutation and genotoxicity thereby paving us way to better prevent the frequency of such mutation and genotoxicity.

\section{References}

1. De Flora S, Izzotti A (2007) Mutagenesis and cardiovascular diseases Molecular mechanisms, risk factors, and protective factors. Mutat Res 621(1-2): 5-17.

2. Natarajan AT(1993) Mechanisms for induction of mutations and chromosome alterations. Environ Health Perspect 101(Suppl 3): 225229.

3. http://iosrjournals.org/iosr-jpbs/papers/vol 1 issue2/P0124354. pdf?id $=4598$

4. Savage JR (1976) Classification and relationships of induced chromosomal structural changes. J Med Genet 13(2): 103-22.

5. Silva RMGd, SousaI NC, Graf U, Spanós MA, (2008) Antigenotoxic effects of Mandevilla velutina (Gentianales, Apocynaceae) crude extract on cyclophosphamide-induced micronuclei in Swiss mice and urethane-induced somatic mutation and recombination in Drosophila melanogaster. Genetic Molecular Biology 31: 751-758.

6. Eker AP, Quayle C, Chaves I, van der Horst GT (2009) DNA repair in Mammalia cells: Direct DNA damage reversal: elegant solutions for nasty problems. Cell Mol Life Sci 66(6): 968-80.

7. Sedgwick B, Bates PA, Paik J, Jacobs SC, Lindahl T (2007) Repair of alkylated DNA: recent advances. DNA Repair (Amst) 6(4): 429-442.

8. Cimino MC (2006) Comparative overview of current international strategies and guidelines for genetic toxicology testing for regulatory purposes. Environ Mol Mutagen 47(5): 362-390.

9. Shah SU (2012) Importance of genotoxicity \& S2a guidelines for genotoxicity testing for pharmaceuticals. Iosr Journal of Pharmacy and Biological Sciences 1(2): 43-54.

10. Philomena G (2011) Concerns regarding the safety and toxicity of medicinal plants -An overview. Journal of Applied Pharmaceutical Science 1(6): 40-44.

11. Goncacak M, Mircigil C (2009) Genotoxicity tests from biomarker studies to the regulations: National perspective. J Pharm Sci 34: 217 32.

12.https://www.intechopen.com/books/microwave-materialscharacterization/experimental-requirements-for-in-vitro-studiesaimed-to-evaluate-the-biological-effects-of-radiofreq

13. Hanahan D, Weinberg RA (2000) The hallmarks of cancer. Cell 100(1): 57-70.

14. Phillips DH, Arlt VM (2009) Genotoxicity: damage to DNA and its consequences. EXS 99: 87-110.

15. Bushra M, Mohammed KJK, Nahi YY (2009) Antimutagenic Effects of Thymus syriacus Extract. J Duhok University 12: 216-226.

16. Tuteja N, Tuteja R (2001) Unravelling DNA repair in human: molecular mechanisms and consequences of repair defect. Crit Rev Biochem Mol Biol 36(3): 261-290.

17. Mourgues S, Lomax ME, O'Neill P, Base excision repair processing of a basic site/single-strand break lesions within clustered damage sites associated with XRCC1 Deficiency. Nucleic Acids Res 35(22): 76767687.

18. Bannister LA, Schimenti JC (2004) Homologous recombinational repair proteins in mouse meiosis. Cytogenet Genome Res 107(3-4): 191-200.

19. Tweats DJ, Scott AD, Westmoreland C, Carmichael PL (2007) Determination of genetic toxicity and potential carcinogenicity in- 
vitro-Challenges post the Seventh Amendment to the European Cosmetics Directive. Mutagenesis 22(1): 5-13.

20. http://www.medscape.com/viewarticle/499098_4.

21. ICH Harmonised Tripartite Guideline S2B (1998). Genotoxicity: A standard battery for genotoxicity testing of pharmaceuticals 3-9.

22. Yamada M, Espinosa AJJ, Watanabe M, Matsui K, Sofuni T, Nohmi $\mathrm{T}$ (1997) Targeted disruption of the gene encoding the classical nitroreductase enzyme in Salmonella typhimurium Ames test strains TA1535 and TA1538. Mutat Res 375(1): 9-17.

23. Clements J (2000) The mouse lymphoma assay. Mutat Res 455(1-2): 97-110.

24. http://www.mindfully.org/Pesticide/Biological-Evaluation-MedDevices-3.htm.

25. Mortelmans K, Zeiger E (2000) The Ames Salmonella/microsome mutagenicity assay. Mutat Res 455(1-2): 29-60.

26. Evans HJ (1976) Cytological Methods for Detecting Chemical Mutagens. Chemical mutagens, Principles and Methods for their Detection 4: 1-29.

27. Maron DM, Ames BN (1983) Revised Methods for the Salmonella Mutagenicity Test. Mutat Res 113(3-4): 173-215.

28. Ames BN, Mccann J, Yamasaki E (1975) Methods for Detecting Carcinogens and Mutagens with the Salmonella/MammalianMicrosome Mutagenicity Test. Mutat Res 31(6): 347-64.

29. Galloway SM, Armstrong MJ, Reuben C, Colman S, Brown B, et al (1978) Chromosome aberration and sister chromatic exchanges in Chinese hamster ovary cells: Evaluation of 108 chemicals. Environ Mo Mutagen 10 (10): 1-175.

30. Ishidate M, Sofuni T (1985) The In-vitro Chromosomal Aberration Test Using Chinese Hamster Lung (CHL) Fibroblast Cells in Culture. Progress in Mutat Res 5: 427-432.

31. Aaron CS, Bolcsfoldi G, Glatt HR, Moore M, Nishi Y, et al. (1994) Mammalian Cell Gene Mutation Assays Working Group Report. Report of the International Workshop on Standardisation of Genotoxicity Test Procedures. Mutat Res 312(3): 235-239.

32. Aaron CS, Stankowski LF (1989) Comparison of the AS52/XPRT and the CHO/HPRT Assays: Evaluation of Six Drug Candidates. Mutation Res 223(2): 121-128.

33. Chu EH, Malling HV (1986) Mammalian Cell Genetics. II. Chemical Induction of Specific Locus Mutations in Chinese Hamster Cells InVitro. Proc Natl Acad Sci U S A 61(4): 1306-1312.

34. Morita T, Nagaki T, Fukuda I, Okumura K (1992) Clastogenicity of low pH to Various Cultured Mammalian Cells. Mutat Res 268(2): 297-305.
35. Richardson, et al. (1989) Analysis of Data from In-Vitro Cytogenetic Assays. In: Statistical Evaluation of Mutagenicity Test Data. Cambridge University Press, Cambridge, USA pp 141-154.

36. Scott D, Galloway SM, Marshall RR, Ishidate M, Brusick D, et al. (1991) International Commission for Protection Against Environmental Mutagens and Carcinogens. Genotoxicity under extreme culture conditions. A report from ICPEMC Task Group 9. Mutat Res 257(2): 147-204.

37. Anderson D, Plewa MJ (1998) The international Comet assay workshop. Mutagenesis 13(1): 67-73.

38. Huang Y, Chang CC, Trosko JE (1983) Aphidicolin-induced endoreduplication in Chinese hamster cells. Cancer Res 43(3): 13621364.

39. Locke HC (1983) Endoreduplication in Chinese hamster cells during alpha-radiation induced G2 arrest. Mutation Res 119(3): 403-413.

40. Liber HL, Thilly WG (1982) Mutation Assay at the Thymidine Kinase Locus in Diploid Human Lymphoblasts. Mutat Res 94(2): 467-485.

41. Moore MM (1987) Banbury Report 28: Mammalian Cell Mutagenesis, Cold Spring Harbor Laboratory, New York, USA.

42. Moore MM, Brock HK, Doerr CL, Dearfield KL (1989) Differential Mutant Quantitation at the Mouse Lymphoma TK and CHO HGPRT Loci. Mutagenesis 4(11): 394-403.

43. Zimmermann FK, von Borstel RC, von Halle ES, Parry JM, Siebert D, et al. (1984) Testing of chemicals for genetic activity with Saccharomyces cerevisiae: a report of the U.S. Environmental Protection Agency GeneTox Program. Mutat Res 133(3): 199-244.

44. Hartmann A, Agurell E, Beevers C, Brendler SS, Burlinson B, et al. (2003) Recommendations for conducting the in-vivo alkaline comet assay. Mutagenesis 18: 45-51.

45. Fenech M, Kirsch VM, Natarajan AT, Surralles J, Crott JW, et al. (2011) Molecular mechanisms of micronucleus, nucleoplasmic bridge and nuclear bud formation in mammalian and human cells. Mutagenesis 26(1): 125-132.

46. Evans HJ, Neary GJ and Williamson FS (1959) The relative biological efficiency of single doses of fast neutrons and gamma-rays on Viciafaba roots and the effect of oxygen. Part II. Chromosome damage: the production of micronuclei. Int J Radiat Biol Relat Stud Phys Chem Med 1: 216-229.

47. Maluf SW, Erdtmann B Genomic instability in Down syndrome and Fanconi anemia assessed by micronucleus analysis and single-cell gel electrophoresis. Cancer Genet Cytogenet 124(1): 71-75.

\begin{tabular}{l} 
Your next submission with Juniper Publishers \\
will reach you the below assets \\
- Quality Editorial service \\
- Swift Peer Review \\
- Reprints availability \\
- E-prints Service \\
- Manuscript Podcast for convenient understanding \\
- Global attainment for your research \\
- Manuscript accessibility in different formats \\
( Pdf, E-pub, Full Text, Audio) \\
- Unceasing customer service \\
Track the below URL for one-step submission \\
https://juniperpublishers.com/online-submission.php \\
\hline
\end{tabular}

